\title{
New trends in museology
}

\section{François Mairesse}

\section{OpenEdition}

\section{Journals}

Electronic version

URL: http://journals.openedition.org/iss/542

DOI: $10.4000 /$ iss. 542

ISSN: 2306-4161

\section{Publisher}

ICOM - International Council of Museums

\section{Printed version}

Date of publication: 1 June 2015

Number of pages: 13-15

ISSN: 2309-1290

\section{Electronic reference}

François Mairesse, "New trends in museology », ICOFOM Study Series [Online], 43a | 2015, Online since 06 February 2018, connection on 21 December 2020. URL : http://journals.openedition.org/iss/542 ; DOI : https://doi.org/10.4000/iss.542 


\title{
New trends in museology
}

\author{
François Mairesse \\ President of ICOFOM - Université Sorbonne nouvelle Paris 3, CERLIS, \\ ICCA, France
}

The International Committee for Museology chose the topic for its 37th symposium, held in Paris from 5 to 9 June 2014, with the idea of opening new directions for thought about the future of museology. Focusing on new trends in museology recognizes that, during the past decades, the world of museums has undergone substantial change. Not only are there are many more museums throughout the world, but they also have radically changed in several ways: the methods of communication (the relation to the display or the development of museums as media); the conversion of heritage; the relation to what is contemporary; or in the approach to the public. The current economic context, with both the expansion of neo-liberal concepts and economic crises, has radically altered the way the museum world thinks. It is not too daring to say that these changes will continue and bring with them new ways to see the museum field through the $21^{\text {st }}$ century. The call for papers, launched at the end of 2013, was made in this context; the committee was resolutely open to collecting innovative abstracts that tried to outline, on a global scale, a panorama of the subjects now emerging in the field of museology. Nine themes were proposed to suggest different lines of thought to authors: geopolitics of museology, or ways to think of the museum field throughout the world; museology as a discipline and subject for teaching; the relation to heritage and the issue of collections, education and communication; the relation to what is current; the outlines of cyber-museology; participatory museology; and museum ethics in the $21^{\text {st }}$ century. The number of proposals received (more than 200 abstracts) called for a strict first selection process -75 presentations were made at the Paris symposium. This is still twice the number of the final selection, which represents the papers edited in volumes $43 \mathrm{a}$ and $43 \mathrm{~b}$ of ICOFOM Study Series.

The profusion of subjects discussed in the different papers made it very difficult to sort them into two volumes. Some subjects were much more favoured than others, requiring a new thematic arrangement. Some trends stood out nevertheless, leading us to sort the papers into two volumes, as well as separating theoretical papers and case studies, the latter being the second part of each volume. We have kept alphabetical order within each volume and section for easier consultation.

Since it was founded, ICOFOM has principally worked on the theoretical aspects of the museum field, starting from a global approach that encompassed all museums and related institutions, as well as the essential museum functions (conservation, research, communication). This approach, adhered to by many ICOFOM members, does not seem to be followed by other researchers. Many papers presented at the symposium and reproduced here underline certain specific aspects of the museum: the institution as a media, exhibitions, conservation, relation to visitors, etc. These choices led us to group in the first volume (no. 43a) those papers that essentially discussed the institution in general, or museology and its evolution; we gathered in the second volume (no. 43b) those papers that 
specifically looked at one particular aspect of the museum phenomenon, whether visitors, museum functions, or the ethical considerations that are linked to them. We realize that sorting in this way can seem artificial, just as it is sometimes difficult to tell the theoretical from the more specific or practical case studies: the borders between theory and practice are far from being clearly set, each one continually nurturing the other.

The first volume of the papers from the symposium (no. 43a) addresses general issues on the future of the museum field and museology. Many papers examine the foundations or history of the field in order to better understand how it may possibly evolve. Deloche returns to basics in order to explore $21^{\text {st }}$ century museology; Guzin also questions a theme dear to ICOFOM: "Museology of the East", while Brulon Soares probes the Nouvelle Muséologie; Menezes de Carvalho and Scheiner examine museology following Pierre Bourdieu's view of the field; in a more practical manner, Gachet traces the history of the Lettre de l'OCIM. Studying training, Bergeron and Carter look at the evolution of museology and its impact on how it is taught. Julião analyses museology's history and its links with museums, while Nomiku focuses on museology's integrity. We know that museology is conceived and taught differently throughout the world. In this perspective Costa develops "southern museology", while Melo, Menezes de Carvalho and de Moraes examine the idea of an "Amazonian museology". Bruno Soares, Menezes de Carvalho and de Vasconcelos take a closer, more practical look at the different currents of museology in Brazil, while Sustar examines pedagogical museums.

Two distinct currents have had considerable impact on how the future of museology is envisaged: the development of digital technology on the one hand, and economic forces on the other. We know the internet and information technologies have influenced museums and thinking about museums' evolution. Cybermuseology is one way to envisage new outlines for the field of museology, as examined by Langlois and then Leshchenko in a more practical approach. The evolution of ways to envision economic mechanisms is critically important for understanding the relations between museums and the art market, which Doyen explains in the ethnographic heritage. However, it is essentially the economic crisis and the attendant development of collaborative and participative action that has had the greatest influence on contemporary museum thinking: the papers of Agostino, Moolhuisen and Radice, among others, are witness to this current working method, so specific to this institution.

The second volume of ISS (no. 43b) refers more directly to museology through museum functions or from the point of view of how they are experienced, in particular from the approach to visitor studies. The issue of how the museum field functions, and in particular the museum itself, raises ethical questions, which are at the heart of the papers by Maranda and Avila Mélendez. Ethics suppose a study of the finalities of museum work, especially thinking about the museum public or its users (potential, current, and future). It is hardly surprising that the issue of visitors and the public is one of the essential avenues for research in the museum field, in particular through studies of the public, as we see in the papers by Harris, Mijalovic and Romanello, Schmitt, Romanello, Crenn and Roustan, and also by Jutant and Lesaffre. The relation between the museum and its public assumes that in some way museums are a 
communication system, a topic discussed by Chuvilova and Shelengina on the one hand, and Roda on the other. This specific link between the museum institution and its public is founded on one of the traditional functions of museums, summed up under the general principles of communication, but more broadly referred to in the ideas of education and, more recently, interpretation and inclusion. Several authors chose this view - Cornélis and Janinon, Dufresne-Tassé, and O'Neil, who emphasized best practices in education and interpretation, and Sant'Anna de Godoy (describing groups of teens and young adults in alphabetisation programmes), de García Ceballos (writing about older groups) and Fontal and Marin (programs for inclusion) or Thévenot et al. (discussing digital natives). All these papers describe details of the museum institution with regard to the groups being cared for. After education and interpretation, the analysis of exhibitions also constitutes a broad avenue for the study of the museum field, whether exhibition techniques or specific experiences linked to creating an exhibition, as decribed by Schärer, Noël-Cadet and Bonniol, and De Caro and, in a more practical vein, Chang and Shibata, or putting the exhibition itself into question, as Camart suggests. The issue of preservation, and more specifically conservation, a subject no less important, is also examined in detail: the image of the conservator is approached by Hoffman, Jones and Burns, while Smeds and Angilis examine the issues of preservation as measured by waste, and, on the other hand, the protecting of intangible heritage through recording the stories of people's lives. Finally, the issue of deaccessioning and restitution is examined by Robbins' study of museums in Finland.

A large number of themes follow the lines of thought launched many years ago. Is it possible that we can now talk about new trends emerging from these papers? It is obvious that these last themes will, in most cases, only emerge from aspects that are already known, even if the need for radical innovation impels us to renew those concepts for better, and sometimes for worse. Moreover, the diverse origin of the papers, written in one of the three working languages of ICOM, underlines the big differences that exist within the world of museology, as much for its stage of development as for its relationship to heritage and the public, and even for the basics of museology. Undoubtedly the study of this diversity is at the heart of the work of ICOFOM: to gather, map out, and make a synthesis of all the ideas linked to the museum field. In this sense, the publication of the Paris symposium only begins to study the trends emerging from current museology, an ongoing and necessarily endless task that amply contributes to certain ideas of empirical research and researchers. 